\title{
Code of Conduct and Corporate Governance
}

\author{
Elisa Arrigo *
}

\begin{abstract}
The code of conduct can be considered a tool of corporate governance because it identifies corporate responsibilities towards stakeholders and obliges top managers to comply with certain guidelines when exercising their authority, both inside and outside the company.

The code of conduct encompasses a wide variety of subjects, because it addresses all the stakeholders who make up the operating scenario. Moreover, it is an expression of the corporate culture since it reveals how the rules of conduct towards the company's interlocutors derive from cultural values and principles.
\end{abstract}

Keywords: Code of Conduct; Corporate Governance; Corporate Governance Communication; Ethics; Global Corporations; Global markets

\section{The Code of Conduct: Structure and Contents}

In a systemic approach, a business is seen as a vital system whose dynamism can be assessed in relation to its capacity to manage relations with the other systematic entities that surround it. As a result, to take the best decisions, the governing board actuates rational processes that define and interpret the environment, in order to identify and classify the other entities on the basis of their influence and importance ${ }^{1}$. In today's hypercompetitive world, company operates in a complex global market and corporate governance becomes essential to regulate the economic and social relationships.

The code of conduct can be considered a tool of corporate governance because it identifies corporate responsibilities towards stakeholders ${ }^{2}$ and obliges top managers to comply with certain guidelines when exercising their authority, both inside and outside the company ${ }^{3}$.

We must distinguish between the code of conduct and the code of ethics: the former, which is 'rules based', aims to offer a solution to every possible situation and helps to outline corporate strategies, i.e. the behaviours to adopt when specific problems emerge; the latter, which is 'value based', provides a set of ethical

* Assistant Professor of Management, University of Milan-Bicocca (elisa.arrigo@ unimib.it)

Edited by: ISTEI - University of Milan-Bicocca

ISSN: $1593-0319$

Arrigo Elisa, Code of Conduct and Corporate Governance, Symphonya. Emerging Issues in Management (symphonya.unimib.it), n. 1, 2006, pp. 93-109

http://dx.doi.org/10.4468/2006.1.07arrigo 
principles and corporate values ${ }^{4}$. The code of conduct is therefore closely linked to the code of ethics because the behaviour to adopt in specific situations depends on the strategic mission principles, and may even incorporate a code of ethics. Many codes place oneself between these two extremes, because they are composed of an introduction that sets out the ethical principles and shared values, and a subsequent section that outlines the rules of conduct to be adopted in certain situations.

Moreover the code of conduct and code of ethics are closely linked to the concepts of integrity and loyalty ${ }^{5}$. In particular, the code of ethics addresses the moral integrity of the individuals in the company, because it identifies the values that employees must respect in their tasks: for example, honesty in their actions, tolerance of diversity and courtesy of service to customers. On the other hand, behaviours dictated by the code of conduct simply requires immediate execution by the members of the organisation, without questioning whether or not it is opportune to do so. As a result, the code of conduct is designed to build strong loyalty to the company among employees. It contributes to create: cohesive and aligned behaviour; organisational efficiency; and better coordination between decisionmaking and functional areas. At the same time, the code of conduct helps to contain internal conflicts by fostering favourable attitudes and consensus towards the company.

The code of conduct encompasses a wide variety of subjects, because it addresses all the stakeholders who make up the operating scenario ${ }^{6}$ in which the corporate management evolves in relation to its environment. Moreover, it is an expression of the corporate culture since it reveals how the rules of conduct towards the company's interlocutors derive from cultural values and principles. The code is therefore structured in two sections: a preamble containing a code's description and the corporate principles, and a section with the rules and the standards of behaviour.

The first section provides a definition of the code of conduct illustrating the mission and the values underpinning it. It then lists the stakeholders with whom the company interacts and defines their expectations and corporate responsibilities, as well as the company's fiduciary duties ${ }^{7}$ in relation to them.

The second part outlines the rules of conduct; these are usually expressed by prohibitions, by recommendations to avoid incorrect behaviour, or simply by listing the standards, i.e. rules and preventive procedures establishing which behaviour must be adopted, and how the company and its collaborators can prevent opportunistic attitudes, so that corporate conduct does not diverge from the established principles.

Research conducted by the OECD of a sample of 236 codes of companies operating in 23 countries has revealed that they regulate working conditions in $60 \%$ of cases, environmental stewardship in $59 \%$, followed by consumer relations (47\%), bribery (20\%) and the transparency of information $(18 \%)^{8}$.

The codes address all individuals or groups that influence certain aspects of corporate strategic behaviour, generating strengths or weaknesses. Although each stakeholder has specific expectations of a proper behaviour by the company, the 
standards concerning him refer to common and shared values such as honesty, justice, fairness and transparency.

Primarily, the codes of conduct address employees, they are institutional stakeholders ${ }^{9}$ and active members of the company. Whit regard to employees, the codes set out the rules to be observed complying with principles of fairness and legality, in order to guarantee a safe working environment and in particular to avoid sex, race or religion discrimination and favouritism in hiring. Some studies show that the adoption of these codes can simplify and increase workers' tolerance of diversity, a crucial issue in the multicultural environments in which global companies operate ${ }^{10}$.

For stockholders, who, like employees, have an institutional vested interest but are non-active members of the company, behaviour standards are designed to prevent improper behaviour and false declarations. The standards that guarantee the external transparency of informative documents are, above all, in the financiers' interest.

Codes of conduct also analyse relations with customers in order to establish a trusting relationship based on an assurance of the safety and characteristics of the product offered, and the standards that regulate relations with suppliers. These focuses, in particular, on the ways the latter operate (for example, not using child labour, respecting the environment, etc.) and on the characteristics of their supply agreements, such as the punctuality of goods deliveries and respect of agreed quality.

The provisions regulating relations with competitors are all based on principles of fairness and respect of anti-trust laws, to avoid unfair conduct. And finally, with regard to the state and the local community, codes of conduct express a company's commitment to act efficiently and profitably, respecting principles of legality and contributing to the economic and social development of its country, by punctual and total payment of its tax liability.

\section{Codes of Conduct and Corporate Governance in Global Corporations}

Corporate governance can refer to the structures and practices by which a company manages the system of internal and external relations with its stakeholders. Two prevalent approaches can be identified: the first encompasses a 'contractualistic' vision of the company and highlights the need to protect the owners' interests (i.e. of those who provide the capital); the second, defined as 'institutionalistic', is based on recognition of a number of entities that influence corporate operations, and therefore considers corporate governance as a condition to guarantee the fair accomplishment of stakeholders' legitimate expectations in the long term, so as to assure to the company the consensus and collaboration that it needs ${ }^{11}$.

Two distinct systems of corporate governance also emerge from the different types of relations with the capital markets with regard to links between ownership and control, i.e.: the 'insider system' and the 'outsider system'. In the former, ownership and control are concentrated in the hands of a small number of majority stockholders who are often members of the same family. The financial market is 
not very efficient, partly because of the strong presence of and pressure from banks in the capital, and the percentage of capital in the hands of other investors is small. In the latter, which can be defined as 'market oriented' and is typical of the AngloSaxon world, ownership is extremely fragmented and it is the market itself that regulates any conflict that arises between owners and management. The company attributes particular attention to the outside in order to attract potential new participants in the corporate risk.

On the basis of relations that can be established between company units, it is also possible to identify two types of structure: one-tier system in which there is one governing board, the Board of Directors, whose role is both administrative and of management and control; and two-tier system in which the management and control functions are separate: the supervisory board will control the management board which only has executive powers ${ }^{12}$.

However, rather than a model of governance, it seems more appropriate to refer to a process ${ }^{13}$ of governance because it regulate relations between the company and its stakeholders, and it therefore evolves dynamically on the basis of environmental changes and the expectations of interlocutors. As a result, it will be difficult to establish standards to be included in models that are valid in all corporate situations, and each company will put in place a specific process of governance on the basis of its own objectives, the competitive context in which it develops and the type of organisational structure.

In networking ${ }^{14}$ processes, in particular, corporate governance is modified on the basis of two dimensions:

- an architectural dimension that separates the networks with strongly asymmetrical powers and a central guide, from those where the branches into the network have equal decision-making powers and operational and strategic decentralisation is in force;

- a regulating dimension that distinguishes between networks created for economic reasons (contracts, price negotiation, etc.) and those for sociopolitical reasons (lobbying, conventions, etc.).

Governance in networks always aims to reduce the structural complexity in order to guarantee the safety of trade by: the definition of a network global strategy; the coordination of the relations between the players in the network; and the monitoring of network unity ${ }^{15}$. However, the ways of concrete implementation vary from one situation to another. One effect of the geographical expansion of the market, typical of corporate networking, and particularly of the greater physicalspatial distance between the stakeholders and the company, is that the possibilities for control that corporate interlocutors can exert on the company system have decreased drastically. In parallel, the stakeholders' need for information, which corporate communication should meet, has increased to the same extent. Corporate communication makes unitary comprehension of corporate phenomena possible, it influences the external evaluation of the company, and constitutes a guide in employees training in order to meet the company's needs ${ }^{16}$.

The code of conduct is one of the tools by which companies can demonstrate their commitment to responsible, sustainable behaviour by disseminating information about their own corporate governance, and meeting the stakeholders' 
growing need for information at least in part. The code of conduct clarifies to stakeholders inside and outside the company the criteria that guide decisions, both strategic and operational, and as well as being a governance tool, it represents the company's constitutional charter, defining the responsibilities of each member of the organisation.

\section{Analysis of the Spread of Codes of Conduct in the Global Markets}

The first one hundred companies from the United States, as classified by Fortune magazine ${ }^{17}$, were analysed to verify the importance that companies attribute to the communication of their corporate governance.

A first examination revealed the presence of communications that were able to qualify the ways in which companies establish their relations with the external environment. In detail, the links included in the cases examined break down as follows:

1. in $65 \%$ of the websites analysed there is an 'about corporate' link,

2. in $12 \%$ an 'investor relations' link,

3 . in $7 \%$ a 'corporate social responsibility' link,

4. in $9 \%$ a 'citizenship' link,

5. in $9 \%$ a 'corporate governance' link,

6. in $6 \%$ an 'environment' link,

7. in 9\% some other link ('host community', 'sustainability', 'our values', etc.).

The link most often present, after the 'about corporate' link, is one that provides information for investors, demonstrating the importance that this group of corporate interlocutors has for company development.

Where the corporate governance communications tools used by the companies analysed are concerned, in no fewer than $58 \%$ of cases a code exists (of conduct or ethics), which is usually incorporated into the corporate governance structure, considered a regulation dictated by the governing board that everyone must respect.

It is followed by the 'corporate social report' (15\%), the 'corporate citizenship report' (14\%), the 'sustainability report' (9\%) and the 'environmental report' (3\%). The percentage for 'other' (45\%) is high because this comprises numerous tools, which are neither reports nor codes, but generally tend to describe the activities performed by the company. It also includes $13 \%$ percentage referred to cases where a charitable foundation, usually created to finance scientific research or to protect Third World children. We can underline that, in the chosen channels of communication and in the tools used, little space has been dedicated to the environment and to sustainable development, while a significant amount of space is dedicated to contributions to society and the surrounding community. This can be explained by the profound consumer culture that exists in the United States, where purchasers, supported by consumer associations, pay considerable attention to the behaviour of companies and are ready to punish any improper conduct. The only companies interested in the environment and in sustainability are, not surprisingly, those with the greatest environmental impact, like the oil company Conoco Philips, and International Paper, a leader of the paper and packaging products sector. 
Figure 1: Percentage spread of corporate governance communication tools

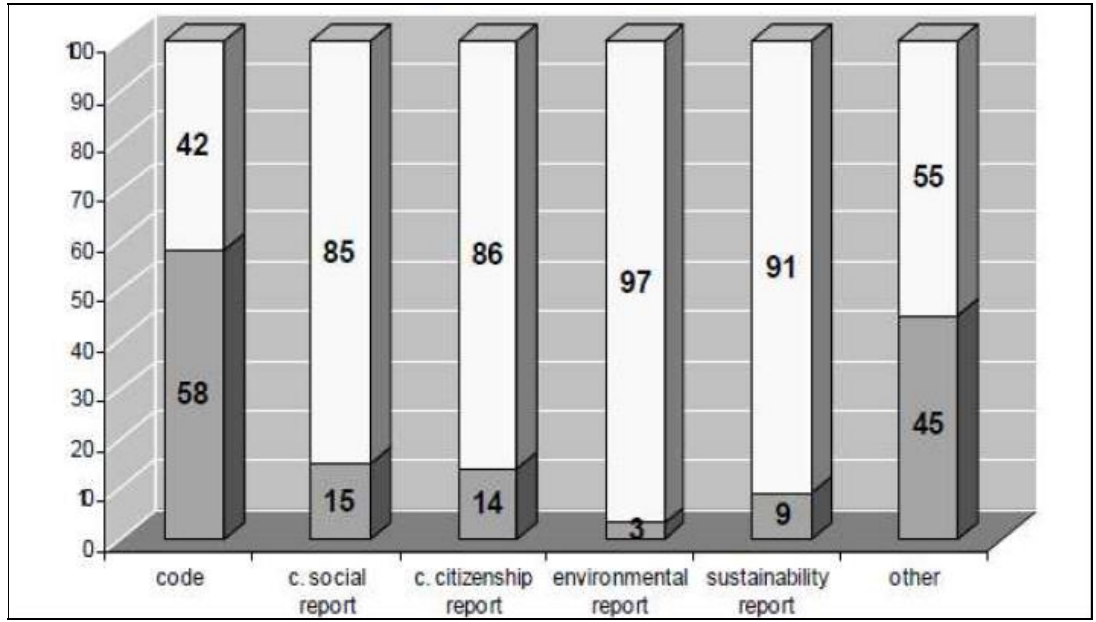

It is interesting to note that often, in the cases analysed, there is no single communication tool but several, usually the code together with a report. This could indicate that most companies prefer to concentrate on a specific tool which provides information about the company's most deep-felt responsibilities; to this the firm adds others that communicate different responsibilities, which are deliberately not described in the same document, in order to keep the issues separate and avoid confusing stakeholders.

Regardless of the type of social commitment or the tool adopted to inform stakeholders, we can note that all the companies taken into consideration communicate information about their relations with the outside environment. However, stakeholders would like more specific information about the ways in which corporate governance is implemented, and this need is generally not satisfied. The reasons can be found in several factors:

1. Companies tend to communicate through their websites, thus excluding a fair number of interested people who do not have access to the Internet.

2. The confusion on websites which do not have a section dedicated specifically to corporate communication or corporate governance, might prevent interested stakeholders from finding all the information they require and might make them assume that these issues are not a priority for the company.

3. The generic and partial nature of information addressing stakeholders, dictated by precise strategic motivations, could be perceived by the latter as behaviour that is not very transparent and therefore 'punishable' by a display of dissent.

\section{Formulation and Dissemination of the Code of Conduct}

The code is introduced in the company at the express request of top management and only subsequently does the elaboration of the document begin, entailing negotiations that involve most of the interested parties. In fact, in order for it to be a useful tool of communication and awareness, the code must be drafted with the 
essential contribution of those it addresses, first and foremost the senior executives $^{18}$.

Although no single procedure exists to draft the code, we can identify a number of steps that are common to all companies. First of all, the definition of the corporate mission, in which the company defines the market that it intends to address, the goals to be reached, the responsibilities it takes on in relation to the stakeholders and the criteria to balance their interests.

In this regard, the seriousness and motivation that prompt the company to disseminate information through the code of conduct are important, because this information underpins the document's credibility inside and outside the company and the thrust of the actions taken by all the stakeholders to comply. If the stimulus is insufficient or non-existent, employees are not motivated to behave correctly, since the code of conduct on its own is not sufficient to guarantee fair behaviour. It is a collection of pronouncements and standards which, to be effective, must be inserted in a vaster project of responsible corporate management ${ }^{19}$. So if the top management is not sufficiently convinced of its utility, adoption of the code of conduct becomes a cosmetic exercise and employees tend to see it as an expedient in the face of public opinion to defend the company from possible illegal behaviour. On the other hand, if the company considers its social responsibility as a factor on which it bases its relationship with the environment, the code of conduct becomes a way in which this sense of responsibility can be formalised and communicated to stakeholders.

After the initiative has been approved by top management, a work team is set up, made up of a coordinator and exponents of the various functional areas who enjoy a direct trusting relationship with top management to guarantee the pursuit of the commitments the latter has entered into. The team has to follow the procedure to elaborate and disseminate the code. Sometimes, because of the complexity of its role, the work group is assisted by external professionals with expertise in the field of business ethics, who are excluded from the process of identifying the values on which the company is founded, but are asked to solve the problems that require specific skills.

This will be followed by a process to map the stakeholders so as to identify the key relationships for the success of the company. The representatives of every stakeholder group, both internal and external, will be consulted through detailed interviews and questionnaires designed to examine the issues of the company's mission, ethical vision, ethical principles, rights and duties ${ }^{20}$. As regards the critical areas identified, rules and standards of conduct are defined and elaboration of the code will then begin with: an analysis of existing documents, taken as a reference; an examination of rules and regulations, corporate policy, Board or Directors minutes; and any other formal or informal texts that can reveal the company's corporate mission and its future orientation.

The formulation of the code is followed by its dissemination and the method employed is extremely significant because it reflects the importance that the company attributes to the code and influences the value judgement attributed to it by employees. If this operation is kept low key it is probable that the code will be perceived as without influence and of little value; to assign the correct importance, it needs to be communicated formally at a specially called meeting, or accompanied 
by a presentation letter signed by the Chairman or Managing Director, underlining its importance for the company ${ }^{21}$.

The code can be disseminated by a 'top-down' or 'bottom-up' method ${ }^{22}$. Usually a top-down or 'cascade' process is chosen: dissemination of the document starts from top management and descends to all hierarchical levels, the top manager delivers a copy of the code to his staff, who in turn communicate it to their subalterns and so on. The second method involves more company levels and functions and envisages a greater degree of involvement of personnel, encouraging discussion of the principles and values on which the company is founded. Both methods have positive and negative aspects: if the company has a strong corporate culture $^{23}$, the code can be introduced with a top-down process in order to strengthen and preserve this culture thus ensuring the lasting development of the company. If in this situation the dissemination were to adopt a bottom-up process, it would be uselessly laborious and could trigger sterile discussions. On the other hand, if the corporate culture is still evolving, a top-down approach could be perceived as an imposition by management, creating resistance among employees. In this case the second system is more advisable because the code is the tool that favours reflection and the evaluation of corporate values and their acceptance throughout the organisation.

It is very important to disseminate the code of conduct to the other corporate key stakeholders and, in particular, to its commercial partners and suppliers, so that they can undertake to adopt the conduct demanded by the company.

For example, IKEA undertakes not to use child labour in its manufacturing stages and to ensure that its suppliers and sub-suppliers do not either. The latter have to sign up to 'The IKEA way on purchasing home furnishing products' which sets minimum requirements that must be respected ${ }^{24}$.

\section{Managing the Code of Conduct: Checks, Sanctions, Reviews and Updates}

After the code has been disseminated, the next problem is to manage it, i.e. checking that the principles it establishes are respected, identifying any incorrect behaviour, imposing any sanctions and reviewing it.

To safeguard the impartiality of the judgements and to give a mark of correctness, management of the code can be entrusted to impartial external professionals, supported by internal employees. However, this does pose the problem of making the most delicate and complex aspects of company activities known to third parties who are not involved in the life of the company. To prevent any conflict from arising between internal and external parties, many companies therefore entrust management of the code to employees alone.

Although no single person or unit is made responsible for checking the effectiveness of the code, responsibility for preventing improper behaviour is often entrusted to the legal office and/or administrative personnel and/or the internal auditors, who are in a position to check that the directives are respected, and can, in certain cases, intervene with top management, the ethics officer ${ }^{25}$ when one exists, 
or the Ethics Committee. This organ, usually part of the staff of the Board of Directors, guarantees an objective viewpoint because its members are chosen from both inside and outside the company. Its duties include collecting the information provided by the auditors, the possibility of judging the offences committed and expressing an opinion to the Board of Directors. To prevent improper behaviour and to check that the principles are respected, it is essential that the code of conduct be communicated inside and outside the company. Only if it is disseminated will the document be able to influence company decisions and behaviour, thus becoming part of the corporate culture. To this end, it is necessary to inform and train all the workforce (executives, managers, white-collars and new employees) with periodical training sessions and workshops ${ }^{26}$ that can first introduce the code and its contents and then teach people how to apply it. It is essential for internal personnel to learn about it in order to activate the mechanisms to signal any deviance from the standards of behaviour, and it must also be communicated to the other significant stakeholders, so that they can judge the company's behaviour on this basis and also demand that it complies. The collaboration of the workforce is essential at the control stage, because the company operates through numerous manifestations and the code of conduct makes it possible to establish a selfregulating system of governance. In fact, the code is only one to govern the behaviour of all members of the global company even with different nationalities, cultures and religions. If the principles and conduct to adopt in specific situations in the life of the company are clearly enunciated, it will be easier for each worker to understand how to behave and to recognise any deviance from standard of behaviour, regardless of his own race, context or background. Obviously, since every individual can report any real or apparent illegal acts that he notes to the competent bodies, it is necessary to act prudently on the allegations of these whistle-blowers ${ }^{27}$ because they may contain false information. In order to avoid this problem, some companies have created the figure of the ombudsman ${ }^{28}$, a person of unquestioned moral rectitude whose role it is to check the truthfulness of the allegations and only then to communicate the offence to the competent bodies.

The principles and general standards of behaviour are therefore essential to evaluate in advance the decisions to take, and to judge the behaviour adopted after the event.

Management of the code of conduct also envisages the determination and imposition of sanctions on those responsible for an offence. Usually, it is up to the immediate superior of the guilty party to establish the entity, and in more serious cases it may be necessary for the company's Managing Director, Chairman, Board of Directors or Ethics Committee to intervene.

Sanctions vary according to the type of violation; the simplest are disapproval or warning letters, but they may go as far as an employee's transfer or even dismissal.

During the implementation and verification stages it may prove necessary to make changes due to shortcomings or incongruences in the original presentation of the contents. In fact, by its very nature, the code must adhere constantly to the situation that it applies to and this implies constant and continuous revision of the document, even with simple adjustments. On the other hand, a review becomes necessary in response to important variations in the corporate structure, for example in the case of mergers, incorporations, acquisitions or changes to the stock 
structure, all operations that entail verification of the consistency of the values on which the company is founded, with its new organisational set-up and approval of the same by the new top management. What is more, it is necessary to monitor whether there have been any changes in the categories of significant stakeholders and in this case, to redefine the expectations and duties in relation to them. The real significance of the code therefore lies in the reason for which it exists and in the way in which it is used; it must not be considered unchangeable and static but as a document in progress that is used by management to verify its own ideas and values and to discuss the corporate identity.

\section{The Effectiveness of the Code of Conduct in Global Corporations}

Where the effectiveness of the code of conduct is concerned, it is interesting to consider whether there is a relationship of complementarity between this document and the rules of the legal system. However, to answer this question, we must distinguish between Common Law Countries, where the legal system is not founded on written rules but on legal precedent and therefore, where the code of conduct is an important document, and Civil Law Countries, like Italy, where the legal system is based on written standards and the significance of the code of conduct is less obvious immediately ${ }^{29}$. In fact, in every situation, the codes sustain the law and encourage the understanding and applicability of the rules that apply inside the company and are not always immediately familiar to employees. In fact it is through their formulation that corporate values can be interiorised in a formal and even more concrete dimension. The code may appear to be the company's response to a demand for supra-national legislation that balances the gaps and the disparities that can arise from the fragmentation of the national legal systems of the various countries in which a global company operates. By implementing it, the company undertakes to impose the standards of conduct wherever it operates.

For this reason, the concepts present in the code are occasionally expressed in generic terms, with few references to concrete cases so that they are adaptable to the many contingencies; whereas, at other times, they are expressed specifically and in great detail. Both methods present positive and negative aspects: an excess of detail is inflexible and any behaviour not mentioned is therefore considered admissible; on the other hand, a lack of precision may imply a lack of clarity and cause hesitation in delicate situations.

The code of conduct is accompanied by a series of conditions influencing its success. First of all is the fact that the code must be a sincere expression of the will of top management and must entail the participation of top executives and of the Board of Directors as well as of employees, so that the content will tend to be closer to the characteristics of the business, constituting an opportunity to develop a sense of belonging to the company. It is also indispensable that the conduct of managers should be an example to all the workforce, who are therefore more motivated to behave properly.

Secondly, values must be communicated with a clear, simple language, that is direct and comprehensible to everyone to avoid misunderstandings and confusion that might be used by people in bad faith to justify illegal acts. The contents must 
not be too generic but focused on the specific characteristics of the sector and the company; their organisation is in line with the description of the company and also includes the management of possible critical situations.

The method adopted to disseminate the code is also important, and the more it underlines the code's importance the more this will be respected and taken into consideration. For this reason, a formal method of dissemination that can highlight its value is advisable. The code must be publicized inside and outside the company; inside, by distributing a copy to all new employees who must sign up to it, as a part of a convention, or by posting it in the workplace. And on the outside, by distributing it to the main stakeholders at dedicated encounters, meetings or training courses ${ }^{30}$.

Once the values have been accepted, a further condition for the effectiveness of the code lies in the involvement of personnel who need constant ethical training that will teach the individual how to deal with any behavioural problems that he may come up against because of his position.

The final condition is the creation of a control structure and a system that can establish the correct sanction for any illegal deed.

\section{Bibliography}

AA. VV., Guida critica alla responsabilità sociale e al governo d'impresa, Bancaria Editrice, Milan, 2006.

Arrigo E., Corporate Responsibility and Hypercompetition. The Ikea Case, Symphonya. Emerging Issues in Management (symphonya.unimib.it), n. 2, 2005. http://dx.doi.org/10.4468/2005.2.04arrigo

Barile S., Gatti M., Corporate Governance e creazione di valore, Atti del Convegno annuale di Sinergie, L'evoluzione del capitalismo tra teoria e prassi: proprietà, governance e valore, 26-27 October 2006, Second University of Naples, Capua.

Bertolini S., Castoldi R., Lago U., I codici etici nella gestione aziendale: l'introduzione e il funzionamento dei codici etici nelle imprese e nelle associazioni in Italia, Il Sole 24 Ore Libri, Milan, 1996.

Brondoni S. M. (ed.), Cultura di Network, Performance e Dinamiche Competitive, Giappichelli, Turin, 2006.

Brondoni S. M., Etica e comunicazioni interne d'azienda, AA.VV., Istituzioni d'economia d'azienda. Scritti in onore di Carlo Masini, Tomo Primo, Egea, Milan, 1993.

Brondoni S. M., Gnecchi F., La comunicazione di Corporate Governance, in Atti del Convegno annuale di Sinergie, L'evoluzione del capitalismo tra teoria e prassi: proprietà, governance e valore, 26-27 October 2006, Second University of Naples, Capua.

Colbert J. L., Corporate Governance: Communications from Internal and External Auditors, Managerial Auditing Journal, vol. 17, n. 3, 2002.

De Colle S., Sacconi L., Il codice etico come strumento di gestione delle relazioni con gli stakeholder, AA.VV., Guida critica alla responsabilità sociale e al governo d'impresa, Bancaria Editrice, Milan 2005.

Deetz S., Corporate Governance, Communication and Getting Social Values Into the Decisional Chain, Management Communication Quarterly, vol. 14, n. 4, May 2003.

http://dx.doi.org/10.1177/0893318902250236 
Di Toro P., L'etica nella gestione d'impresa, Cedam, Padua, 1993.

Ehlinger S., Perret V., Chabaud D., Quelle gouvernance pour les réseaux territorialisés d'organisations?, Revue Française de Gestion, vol. 33, n. 170, 2007.

http://dx.doi.org/10.3166/rfg.170.155-171

Fiori G., Tiscini R., di Donato F., Corporate governance, evoluzione della normativa ed informazione esterna d'impresa, D.M. Salvioni (ed.), Corporate Governance e sistemi di controllo della gestione aziendale, Franco Angeli, Milan, 2004.

Fischer C., Managers' Perceptions of Ethical Codes: Dialectics and Dynamics, Business Ethics: a European Review, vol. 10, n. 2, 2001.

Freeman R. E., Strategic Management. A Stakeholder Approach, Pitman, 1984.

Golinelli G. M., L'impresa sistema vitale. L'approccio sistemico al governo dell'impresa, vol. 1, Cedam, Padua, 2000.

OCSE, Principi di governo societario, 2004.

OECD, Codes of Corporate Conduct: Expanded Review of Their Contents, Working Papers on International Investment, n. 6, 2001.

Pelfrey S., Peacock E., Ethical Codes of Conduct Are Improving, Business Forum, Spring, vol. 16, n. 2, 1991.

Pilotti L., Rullani E., Corporate Governance e società della conoscenza, in Atti del Convegno annuale di Sinergie, L'evoluzione del capitalismo tra teoria e prassi: proprietà, governance e valore, 26-27 October 2006, Second University of Naples, Capua.

Riolo F., Etica degli affari e codici etici aziendali, Edibank, Milan, 1995.

Robin D., Giallourakis M., David F., Moritz T., A Different Look at Codes of Ethics, Business Horizons, vol. 32, n. 1, 1989. http://dx.doi.org/10.1016/0007-6813(89)90028-1

Sacchettoni M., Il codice etico, il codice di condotta: carta di valori o norme non condivise?, G. Felici (ed.), Dall'etica ai codici etici. Come l'etica diventa progetto d'impresa, Franco Angeli, Milan, 2005.

Salvioni D.M. (ed.), Corporate Governance e sistemi di controllo della gestione aziendale, Franco Angeli, Milan, 2004.

Salvioni D.M., Corporate Governance and Global Responsibility, Symphonya. Emerging Issues in Management (symphonya.unimib.it), n. 1, 2003.

http://dx.doi.org/10.4468/2003.1.05salvioni

Sciascia M., L'autoregolazione dei comportamenti delle imprese tra etica e diritto: il Codice Etico, Working Paper, (www.eticare.it) .

Valentine S., Fleischman G., Code of ethics and Professionals' Tolerance of Societal Diversity, Journal of Business Ethics, vol. 40, n. 4, 2002.

\section{Notes}

${ }^{1}$ Cf. G. Golinelli, L'impresa sistema vitale. L'approccio sistemico al governo dell'impresa, vol. 1, Cedam, Padua, 2000.

${ }^{2}$ Cf. R. E. Freeman, Strategic Management. A Stakeholder Approach, Pitman, 1984.

${ }^{3}$ Cf. AA.VV., Guida critica alla responsabilità sociale e al governo d'impresa, Bancaria Editrice, 2006. 
${ }^{4}$ Cf. S. Pelfrey, E. Peacock, Ethical codes of conduct are improving, in Business Forum, Spring, vol. 16, n. 2, 1991; D. Robin, M. Giallourakis, F. David, T. Moritz, A Different Look at Codes of Ethics, in Business Horizons, vol. 32, n. 1, 1989; D.M. Salvioni (edited by), Corporate Governance e sistemi di controllo della gestione aziendale, FrancoAngeli, Milan, 2004.

5 Cf. C. Fisher, Managers' Perceptions of Ethical Codes: Dialectics and Dynamics, Business Ethics: A European Review, vol. 10, n. 2, 2001.

${ }^{6}$ Cf. P. Di Toro, L'etica nella gestione d'impresa, Cedam, Padua, 1993.

${ }^{7}$ A party has a legitimate interest, but is unable to take the significant decisions and delegates the decision to a person he trusts, who has authority for the choice of actions and objectives, but the interests of the truster represent legitimate claims in relation to the trustee, generating duties for the person with authority, for which he has to 'answer'. Cf. AA.VV., Guida critica alla responsabilità sociale e al governo d'impresa, Bancaria Editrice, Milan, 2006.

${ }^{8}$ Cf. OECD, Codes of Corporate Conduct: Expanded Review of Their Contents, Working Papers on International Investment, n. 6, 2001.

${ }^{9}$ Cf. S. Bertolini, R. Castoldi, U. Lago, I codici etici nella gestione aziendale, Il Sole 24 Ore Libri, Milan, 1996.

${ }^{10}$ Cf. S. Valentine, G. Fleischman, Code of Ethics and Professionals' Tolerance of Societal Diversity, Journal of Business Ethics, vol. 40, n. 4, 2002.

${ }^{11}$ Cf. S. Barile, M. Gatti, Corporate Governance e creazione di valore, in Atti del Convegno Annuale di Sinergie, L'evoluzione del capitalismo tra teoria e prassi: proprietà, governance e valore, 26-27 October 2006, Second University of Naples, Capua.

12 Cf. S.M. Brondoni, F. Gnecchi, La comunicazione di Corporate Governance, in Atti del Convegno annuale di Sinergie, L'evoluzione del capitalismo tra teoria e prassi: proprietà, governance e valore, 26-27 October 2006, Second University of Naples, Capua.

13 Cf. L. Pilotti, E. Rullani, Corporate Governance e società della conoscenza, in Atti del Convegno annuale di Sinergie, L'evoluzione del capitalismo tra teoria e prassi: proprietà, governance e valore, 26-27 October 2006, Second University of Naples, Capua.

14 Cf. S.M. Brondoni (ed.), Cultura di Network, Performance e Dinamiche Competitive, Giappichelli, Turin, 2006.

15 Cf. S. Ehlinger, V. Perret, D. Chabaud, Quelle governance pour les réseaux territorialisés d'organisations?, Revue Française de Gestion, vol. 33, n. 170, 2007.

16 Cf. S. Deetz, Corporate Governance, Communication and Getting Social Values Into the Decisional Chain, in Management Communication Quarterly, vol. 16, n. 4, May 2003.

${ }^{17}$ U.S. companies have been classified by the magazine Fortune on the basis of their sales, in millions of Dollars, of 2005. We accessed the website of each company to verify the presence and the quantity of information regarding relations between the company and the outside world. Attached: the list of the companies analysed and the analyses performed.

Cf. (http://money.cnn.com/magazines/fortune/fortune500/full_list/).

${ }^{18}$ Cf. M. Sacchettoni, Il codice etico, il codice di condotta: carta di valori o norme non condivise? in G. Felici (edited by), Dall'etica ai codici etici. Come l'etica diventa progetto d'impresa, Franco Angeli, Milan, 2005.

${ }^{19}$ Cf. E. Arrigo, Corporate Responsibility and Hypercompetition. The Ikea Case, Symphonya. Emerging Issues in Management (symphonya.unimib.it), n. 2, 2005.

${ }^{20}$ Cf. M. Sciascia, L' autoregolazione dei comportamenti delle imprese tra etica e diritto: il Codice Etico, Working Paper, (www.eticare.it). 
${ }^{21}$ Cf. S. Bertolini, R. Castoldi, U. Lago, I codici etici nella gestione aziendale: l'introduzione e il funzionamento dei codici etici nelle imprese e nelle associazioni in Italia, Il Sole 24 Ore Libri, Milan, 1996.

22 Ibid.

${ }^{23}$ In addition to the corporate culture, also the consensus management has a dominant influence. For further detail, we refer you to S.M. Brondoni, Etica e comunicazioni interne d'azienda, in AA.VV, Istituzioni d'economia d'azienda. Scritti in onore di Carlo Masini, Tomo Primo, Egea, Milan, 1993.

${ }^{24}$ Cf. E. Arrigo, Corporate Responsibility and Hypercompetition. The Ikea Case, Symphonya. Emerging Issues in Management (symphonya.unimib.it), n. 2, 2005.

25 The Ethics officer is generally an operational figure who, in addition to dealing with the dissemination of the code, receives the allegations of violations and interfaces with the Committee. Cf. M. Sacchettoni, Il codice etico, il codice di condotta: carta di valori o norme non condivise? in G. Felici (edited by), Dall'etica ai codici etici. Come l'etica diventa progetto d'impresa, FrancoAngeli, Milan, 2005; F. Riolo, Etica degli affari e codici etici aziendali, Edibank, Milan, 1995.

${ }^{26}$ Cf. S. Valentine, G. Fleischman, Code of Ethics and Professionals' Tolerance of Societal Diversity, iJournal of Business Ethics; vol. 40, n. 4, Nov. 2002.

${ }^{27}$ Cf. S. Bertolini, R. Castaldi, U. Lago, I codici etici nella gestione aziendale: l'introduzione e il funzionamento dei codici etici nelle imprese e nelle associazioni in Italia, Il Sole 24 Ore Libri, Milan, 1996.

${ }^{28}$ Ibid.

${ }^{29}$ Cf. F. Riolo, Etica degli affari e codici etici aziendali, Edibank, Milan, 1995.

${ }^{30}$ Cf. J.L. Colbert, Corporate Governance: Communications from Internal and External Auditors, Managerial Auditing Journal, vol. 17, n. 3, 2002. 
Attachment: Analysis of the First 100 Companies in the Global 500 Listed by Fortune

\begin{tabular}{|c|c|c|c|c|c|c|c|c|c|c|c|c|c|c|c|c|c|}
\hline \multirow[b]{2}{*}{ 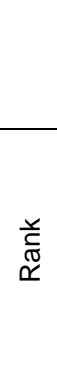 } & \multirow[b]{2}{*}{ 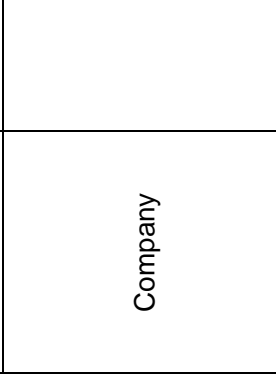 } & \multirow[b]{2}{*}{ 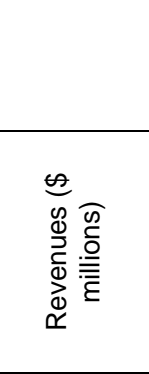 } & \multirow[b]{2}{*}{ 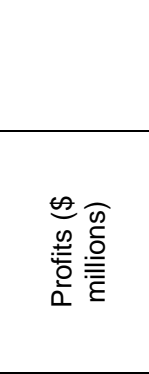 } & \multicolumn{6}{|c|}{ SOCIAL COMMITMENT } & \multicolumn{8}{|c|}{$\begin{array}{l}\text { CORPORATE GOVERNANCE } \\
\text { COMMUNICATION TOOL USED }\end{array}$} \\
\hline & & & & $\begin{array}{l}\frac{r}{5} \\
0 \\
\underline{\underline{J}} \\
=\end{array}$ & 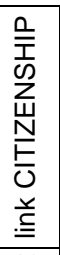 & 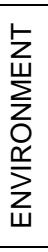 & 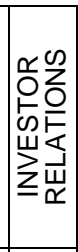 & 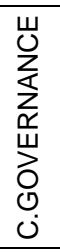 & 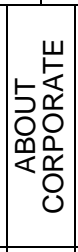 & 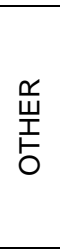 & 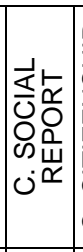 & 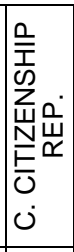 & 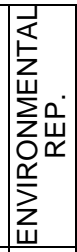 & 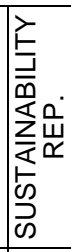 & 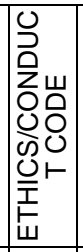 & 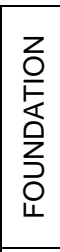 & $\begin{array}{l}\frac{q}{w} \\
\text { 뭉 }\end{array}$ \\
\hline 1 & Exxon Mobil (XOM) & $339,938.0$ & $36,130.0$ & & $\mathrm{X}$ & & & & & & & $\mathrm{X}$ & & & & & \\
\hline 2 & $\begin{array}{l}\text { Wal-Mart Stores } \\
\text { (WMT) }\end{array}$ & $315,654.0$ & $11,231.0$ & & & $\mathrm{X}$ & $\mathrm{X}$ & & & $\mathrm{X}$ & & & & & $\mathrm{X}$ & $\mathrm{X}$ & \\
\hline 3 & $\begin{array}{l}\text { General Motors } \\
(\mathrm{GM})\end{array}$ & $192,604.0$ & $-10,600.0$ & & & & & & $\mathrm{x}$ & & $\mathrm{x}$ & & & & & & \\
\hline 4 & Chevron (CVX) & $189,481.0$ & $14,099.0$ & $\mathrm{X}$ & & $\mathrm{X}$ & & & & & $\mathrm{X}$ & & & & & & \\
\hline 5 & Ford Motor (F) & $177,210.0$ & $2,024.0$ & $\mathrm{X}$ & & & & & & & & & & & $\mathrm{X}$ & & \\
\hline 6 & $\begin{array}{l}\text { ConocoPhillips } \\
\text { (COP) }\end{array}$ & $166,683.0$ & $13,529.0$ & & & $\mathrm{x}$ & & & $\mathrm{X}$ & $\mathrm{x}$ & & & & $\mathrm{X}$ & & $\mathrm{x}$ & \\
\hline 7 & $\begin{array}{l}\text { General Electric } \\
(\mathrm{GE})\end{array}$ & $157,153.0$ & $16,353.0$ & & $\mathrm{x}$ & & & & & & & $\mathrm{x}$ & & & & & \\
\hline 8 & Citigroup (C) & $131,045.0$ & $24,589.0$ & & $\mathrm{X}$ & & & & & & & $\mathrm{X}$ & & & & $\mathrm{X}$ & $\mathrm{X}$ \\
\hline 9 & $\begin{array}{ll}\text { American } & \text { Intl. } \\
\text { Group (AIG) } & \\
\end{array}$ & $108,905.0$ & $10,477.0$ & $\mathrm{x}$ & & & & & & & & & & & $\mathrm{X}$ & & $\mathrm{X}$ \\
\hline 10 & $\begin{array}{ll}\text { Intl. } & \text { Business } \\
\text { Machines (IBM) }\end{array}$ & $91,134.0$ & $7,934.0$ & & & & & & $\mathrm{X}$ & & $\mathrm{X}$ & & & & & & \\
\hline 11 & $\begin{array}{l}\text { Hewlett-Packard } \\
\text { (HPQ) }\end{array}$ & $86,696.0$ & $2,398.0$ & & & & & & $\mathrm{X}$ & & & $\mathrm{X}$ & & & $\mathrm{X}$ & & \\
\hline 12 & $\begin{array}{l}\text { Bank of America } \\
\text { Corp. (BAC) }\end{array}$ & $83,980.0$ & $16,465.0$ & & & & & & $\mathrm{X}$ & & & & & & $\mathrm{X}$ & & $\mathrm{X}$ \\
\hline 13 & $\begin{array}{l}\text { Berkshire } \\
\text { Hathaway (BRKA) }\end{array}$ & $81,663.0$ & $8,528.0$ & & & & & $\mathrm{X}$ & & & & & & & $\mathrm{X}$ & & \\
\hline 14 & Home Depot (HD) & $81,511.0$ & $5,838.0$ & & & & & & $\mathrm{X}$ & & $\mathrm{X}$ & & & & & & \\
\hline 15 & $\begin{array}{ll}\begin{array}{l}\text { Valero } \\
\text { (VLO) }\end{array} & \text { Energy } \\
\end{array}$ & $81,362.0$ & $3,590.0$ & & & $\mathrm{x}$ & & $\mathrm{X}$ & & $\mathrm{X}$ & & & & & $\mathrm{X}$ & & \\
\hline 16 & McKesson (MCK) & $80,514.6$ & -156.7 & & $\mathrm{X}$ & & & & & & & & & & $\mathrm{X}$ & & $\mathrm{X}$ \\
\hline 17 & $\begin{array}{l}\text { J.P. Morgan Chase } \\
\text { \& Co. (JPM) }\end{array}$ & $79,902.0$ & $8,483.0$ & & & & & & $\mathrm{X}$ & $\mathrm{X}$ & & & & & $\mathrm{X}$ & & \\
\hline 18 & $\begin{array}{l}\text { Verizon } \\
\text { Communications } \\
\text { (VZ) }\end{array}$ & $75,111.9$ & $7,397.0$ & & & & & & $\mathrm{x}$ & & & & & & & $\mathrm{x}$ & \\
\hline 19 & $\begin{array}{l}\text { Cardinal Health } \\
(\mathrm{CAH})\end{array}$ & $74,915.1$ & $1,050.7$ & & & & & & $\mathrm{x}$ & & & & & & & $\mathrm{x}$ & $x$ \\
\hline 20 & Altria Group (MO) & $69,148.0$ & $10,435.0$ & $\mathrm{X}$ & & & & & & & & & & & $\mathrm{X}$ & & \\
\hline 21 & Kroger (KR) & $60,552.9$ & 958.00 .00 & & & & & & $\mathrm{X}$ & & $\mathrm{X}$ & & & & & & \\
\hline 22 & $\begin{array}{l}\text { State } \\
\text { Insurance Cos }\end{array}$ & $59,223.9$ & $3,241.8$ & & & & & & $\mathrm{X}$ & & & & & & $\mathrm{x}$ & & \\
\hline 23 & $\begin{array}{l}\text { Marathon Oil } \\
(\mathrm{MRO})\end{array}$ & $58,958.0$ & $3,032.0$ & & & & & & & $\mathrm{X}$ & & & & & $\mathrm{x}$ & & $\mathrm{x}$ \\
\hline 24 & $\begin{array}{l}\text { Procter \& Gamble } \\
\text { (PG) }\end{array}$ & $56,741.0$ & $7,257.0$ & & & & & & $\mathrm{x}$ & & & & & $\mathrm{X}$ & & & $\mathrm{x}$ \\
\hline 25 & Dell (DELL) & $55,908.0$ & $3,572.0$ & & & & & & $\mathrm{X}$ & & & & & $\mathrm{X}$ & $\mathrm{X}$ & & \\
\hline 26 & Boeing (BA) & $54,848.0$ & $2,572.0$ & & & & & & $\mathrm{X}$ & & & & & & $\mathrm{X}$ & $\mathrm{X}$ & $\mathrm{X}$ \\
\hline 27 & $\begin{array}{l}\text { AmerisourceBerge } \\
\mathrm{n}(\mathrm{ABC})\end{array}$ & $54,589.6$ & 264.06 .00 & & & & & & $\mathrm{x}$ & & & & & & & & $\mathrm{X}$ \\
\hline 28 & $\begin{array}{l}\text { Costco Wholesale } \\
\text { (COST) }\end{array}$ & $52,935.2$ & $1,063.1$ & & & & $\mathrm{X}$ & & & & & & & & $\mathrm{x}$ & & \\
\hline 29 & Target (TGT) & $52,620.0$ & $2,408.0$ & & & & & & $\mathrm{X}$ & & $\mathrm{X}$ & & & & & & \\
\hline 30 & $\begin{array}{l}\text { Morgan Stanley } \\
\text { (MS) }\end{array}$ & $52,498.0$ & $4,939.0$ & & & & & & $\mathrm{x}$ & & & & & & $\mathrm{X}$ & & \\
\hline 31 & Pfizer (PFE) & $51,353.0$ & $8,085.0$ & & $\mathrm{X}$ & & & & & & & $\mathrm{X}$ & & & & & \\
\hline
\end{tabular}




\begin{tabular}{|c|c|c|c|c|c|c|c|c|c|c|c|c|c|c|c|c|c|}
\hline 32 & $\begin{array}{l}\text { Johnson \& Johnson } \\
\text { (JNJ) }\end{array}$ & $50,514.0$ & $10,411.0$ & $\mathrm{x}$ & & & & & & & & & & $\mathrm{x}$ & & & \\
\hline 33 & $\begin{array}{ll}\text { Sears } & \text { Holdings } \\
\text { (SHLD) } & \\
\end{array}$ & $49,124.0$ & 858.00 .00 & & & & & $\mathrm{x}$ & & & & & & & $\mathrm{X}$ & & $\mathrm{x}$ \\
\hline 34 & Merrill Lynch (MER) & $47,783.0$ & $5,116.0$ & & & & & & $\mathrm{X}$ & & & & & & $\mathrm{X}$ & & \\
\hline 35 & MetLife (MET) & $46,983.0$ & $4,714.0$ & & & & & & $x$ & & & & & & & $x$ & $x$ \\
\hline 36 & $\begin{array}{ll}\text { Dow } & \text { Chemical } \\
\text { (DOW) } & \\
\end{array}$ & $46,307.0$ & $4,515.0$ & & & & & & $\mathrm{X}$ & & & & & & & & $\mathrm{X}$ \\
\hline 37 & $\begin{array}{l}\text { UnitedHealth } \\
\text { Group (UNH) }\end{array}$ & $45,365.0$ & $3,300.0$ & & & & & & $X$ & & & & & & $\mathrm{X}$ & & \\
\hline 38 & Wellpoint (WLP) & $45,136.0$ & $2,463.8$ & & & & & $\mathrm{X}$ & & & & & & & $\mathrm{X}$ & & \\
\hline 39 & AT\&T (T) & $43,862.0$ & $4,786.0$ & & & $\mathrm{X}$ & & & $\mathrm{X}$ & $\mathrm{X}$ & & & & & & & $\mathrm{X}$ \\
\hline 40 & $\begin{array}{l}\begin{array}{l}\text { Time } \\
(T W X)\end{array} \\
(T \text { Warner }\end{array}$ & $43,652.0$ & $2,905.0$ & & $\mathrm{X}$ & & & & & & $\mathrm{x}$ & & & & & & \\
\hline 41 & $\begin{array}{ll}\text { Goldman } & \text { Sachs } \\
\text { Group (GS) } & \end{array}$ & $43,391.0$ & $5,626.0$ & & & & & & $\mathrm{X}$ & & & & $\mathrm{X}$ & & & $\mathrm{x}$ & \\
\hline 42 & Lowe's (LOW) & $43,243.0$ & $2,771.0$ & & & & & & $\mathrm{X}$ & & $\mathrm{X}$ & & & & & & \\
\hline 43 & $\begin{array}{l}\text { United } \\
\text { Technologies } \\
\text { (UTX) }\end{array}$ & $42,725.0$ & $3,069.0$ & $\mathrm{X}$ & & & & & & & $\mathrm{X}$ & & & & & & \\
\hline 44 & $\begin{array}{l}\text { United Parcel } \\
\text { Service (UPS) }\end{array}$ & $42,581.0$ & $3,870.0$ & & & & $\mathrm{x}$ & & & & & & & & $\mathrm{X}$ & & $\mathrm{X}$ \\
\hline 45 & Walgreen (WAG) & $42,201.6$ & $1,559.5$ & & & & $\mathrm{X}$ & & & & & & & & $\mathrm{X}$ & & \\
\hline 46 & Wells Fargo (WFC) & $40,407.0$ & $7,671.0$ & & & & & & $\mathrm{X}$ & & & $\mathrm{X}$ & & & & & \\
\hline 47 & Albertson's (ABS) & $40,397.0$ & 446.00 .00 & & & & & & $\mathrm{X}$ & $\mathrm{X}$ & & & & & & $\mathrm{X}$ & $\mathrm{X}$ \\
\hline 48 & Microsoft (MSFT) & $39,788.0$ & $12,254.0$ & & & & & & $\mathrm{X}$ & & & $\mathrm{X}$ & & & & & \\
\hline 49 & Intel (INTC) & $38,826.0$ & $8,664.0$ & & & & & & $\mathrm{X}$ & & $\mathrm{X}$ & & & & $\mathrm{X}$ & & \\
\hline 50 & Safeway (SWY) & $38,416.0$ & 561.01 .00 & & & & $\mathrm{X}$ & & $\mathrm{X}$ & & & & & & $\mathrm{X}$ & $x$ & \\
\hline 51 & $\begin{array}{l}\text { Medco Health } \\
\text { Solutions (MHS) }\end{array}$ & $37,870.9$ & 602.00 .00 & & & & $\mathrm{x}$ & & & & & & & & $\mathrm{x}$ & $\mathrm{x}$ & \\
\hline 52 & $\begin{array}{l}\text { Lockheed Martin } \\
\text { (LMT) }\end{array}$ & $37,213.0$ & $1,825.0$ & & & & & & $\mathrm{X}$ & & & $\mathrm{x}$ & & & $\mathrm{x}$ & & \\
\hline 53 & CVS (CVS) & $37,006.2$ & $1,224.7$ & & & & $\mathrm{X}$ & & & & & & & & $\mathrm{X}$ & & \\
\hline 54 & Motorola (MOT) & $36,843.0$ & $4,578.0$ & & & & & & $\mathrm{X}$ & & & $\mathrm{X}$ & & & & & \\
\hline 55 & Caterpillar (CAT) & $36,339.0$ & $2,854.0$ & & & & & & & $\mathrm{X}$ & & & & & $\mathrm{X}$ & & \\
\hline 56 & $\begin{array}{l}\text { Archer Daniels } \\
\text { Midland (ADM) }\end{array}$ & $35,943.8$ & $1,044.4$ & & & & & & $\mathrm{X}$ & & & & & & $\mathrm{X}$ & & \\
\hline 57 & $\begin{array}{l}\text { Wachovia Corp. } \\
\text { (WB) }\end{array}$ & $35,908.0$ & $6,643.0$ & & & & $\mathrm{X}$ & & & & & & & & $\mathrm{X}$ & $\mathrm{x}$ & $\mathrm{X}$ \\
\hline 58 & Allstate (ALL) & $35,383.0$ & $1,765.0$ & & & & & & $\mathrm{X}$ & & $\mathrm{X}$ & & & & & & \\
\hline 59 & Sprint Nextel (S) & $34,680.0$ & $1,785.0$ & & & & & & $\mathrm{X}$ & & & & & & $\mathrm{X}$ & & \\
\hline 60 & $\begin{array}{l}\text { Caremark } \quad \mathrm{Rx} \\
(\mathrm{CMX})\end{array}$ & $32,991.3$ & 932.04 .00 & & & & & $\mathrm{X}$ & $\mathrm{x}$ & & & & & & $\mathrm{X}$ & & \\
\hline 61 & PepsiCo (PEP) & $32,562.0$ & $4,078.0$ & & $\mathrm{X}$ & & & & & & & & & & $\mathrm{X}$ & & \\
\hline 62 & $\begin{array}{l}\text { Lehman Brothers } \\
(\text { LEH) }\end{array}$ & $32,420.0$ & $3,260.0$ & & & & & & $\mathrm{X}$ & & & $\mathrm{x}$ & & & & & $\mathrm{X}$ \\
\hline 63 & Walt Disney (DIS) & $31,944.0$ & $2,533.0$ & & & & & & $\mathrm{X}$ & & & & & & $\mathrm{X}$ & & \\
\hline 64 & $\begin{array}{l}\text { Prudential Financial } \\
\text { (PRU) }\end{array}$ & $31,708.0$ & $3,540.0$ & & & & & & $\mathrm{x}$ & & & $\mathrm{X}$ & & & & $\mathrm{X}$ & $\mathrm{x}$ \\
\hline 65 & $\begin{array}{l}\text { Plains All Amer. } \\
\text { Pipeline (PAA) }\end{array}$ & $31,177.3$ & 217.08 .00 & & & & & & $\mathrm{x}$ & & & & & & $\mathrm{X}$ & & \\
\hline 66 & Sunoco (SUN) & $31,176.0$ & 974.00 .00 & & & & & & $\mathrm{X}$ & & & & & & $\mathrm{X}$ & & $\mathrm{X}$ \\
\hline 67 & $\begin{array}{l}\text { Northrop Grumman } \\
\text { (NOC) }\end{array}$ & $30,721.0$ & $1,400.0$ & & & & & & $\mathrm{X}$ & & & & & & $\mathrm{x}$ & & \\
\hline 68 & Sysco (SYY) & $30,281.9$ & 961.05 .00 & & & & & $\mathrm{X}$ & & & & & & & $\mathrm{X}$ & & \\
\hline 69 & $\begin{array}{l}\text { American Express } \\
(\mathrm{AXP})\end{array}$ & $30,080.0$ & $3,734.0$ & & & & $\mathrm{x}$ & & $\mathrm{X}$ & & & & & & $\mathrm{x}$ & & \\
\hline 70 & FedEx (FDX) & $29,363.0$ & $1,449.0$ & & & & & & $\mathrm{X}$ & & & & & & $x$ & & \\
\hline 71 & $\begin{array}{l}\text { Honeywell Intl. } \\
(\mathrm{HON})\end{array}$ & $28,862.0$ & $1,655.0$ & & & & & & $\mathrm{X}$ & & & & & & $\mathrm{X}$ & & \\
\hline 72 & Ingram Micro (IM) & $28,808.3$ & 216.09 .00 & & & & $\mathrm{X}$ & & & & & & & & $\mathrm{x}$ & & \\
\hline 73 & DuPont (DD) & $28,491.0$ & $2,053.0$ & & & & & & $\mathrm{X}$ & & & & & & $\mathrm{X}$ & & \\
\hline 74 & $\begin{array}{l}\text { New York Life } \\
\text { Insurance }\end{array}$ & $28,051.0$ & $1,421.6$ & & & & & & $X$ & & & & & & & $\mathrm{x}$ & \\
\hline 75 & $\begin{array}{l}\text { Johnson Controls } \\
\text { (JCl) }\end{array}$ & $28,019.5$ & 909.04 .00 & & & & & & $X$ & & & & & $\mathrm{X}$ & & & \\
\hline 76 & Best Buy (BBY) & $27,433.0$ & 984.00 .00 & & & & $\mathrm{X}$ & & & & $\mathrm{X}$ & & & & $\mathrm{X}$ & $\mathrm{X}$ & \\
\hline 77 & Delphi (DPHIQ) & $27,201.0$ & $-6,369.0$ & $\mathrm{X}$ & & & & & & & & & & & & $\mathrm{x}$ & \\
\hline
\end{tabular}


(C) SYMPHONYA Emerging Issues in Management, n. 1, 2006

symphonya.unimib.it

\begin{tabular}{|c|c|c|c|c|c|c|c|c|c|c|c|c|c|c|c|c|c|}
\hline 78 & $\begin{array}{l}\text { Hartford Financial } \\
\text { Services (HIG) }\end{array}$ & $27,083.0$ & $2,274.0$ & & & & & & $\mathrm{X}$ & & & & & & $\mathrm{X}$ & & $x$ \\
\hline 79 & Alcoa $(\mathrm{AA})$ & $26,601.0$ & $1,233.0$ & & & & & & $\mathrm{X}$ & & & & & $\mathrm{X}$ & & & $\mathrm{X}$ \\
\hline 80 & Tyson Foods (TSN) & $26,014.0$ & 353.00 .00 & & & & & & $\mathrm{X}$ & & & & & $\mathrm{X}$ & & & \\
\hline 81 & TIAA-CREF & $25,916.8$ & $2,000.8$ & & & & & $\mathrm{X}$ & & & & & & & & & $\mathrm{X}$ \\
\hline 82 & $\begin{array}{l}\text { International Paper } \\
\text { (IP) }\end{array}$ & $25,797.0$ & $1,100.0$ & & & $\mathrm{x}$ & & & $\mathrm{X}$ & & & & & $\mathrm{X}$ & $\mathrm{X}$ & $\mathrm{X}$ & $\mathrm{X}$ \\
\hline 83 & $\begin{array}{ll}\text { Cisco } & \text { Systems } \\
(\mathrm{CSCO}) & \\
\end{array}$ & $24,801.0$ & $5,741.0$ & & & & & & $\mathrm{x}$ & $\mathrm{X}$ & & $\mathrm{X}$ & & & $\mathrm{X}$ & & \\
\hline 84 & $\mathrm{HCA}(\mathrm{HCA})$ & $24,455.0$ & $1,424.0$ & & & & & & $\mathrm{X}$ & & & & & & $\mathrm{X}$ & & \\
\hline 85 & $\begin{array}{l}\text { St. Paul Travelers } \\
\text { Cos. (STA) }\end{array}$ & $24,365.0$ & $1,622.0$ & & & & & & $\mathrm{X}$ & & & & & & & & $\mathrm{X}$ \\
\hline 86 & News Corp. (NWS) & $23,859.0$ & $2,128.0$ & & & & & $\mathrm{X}$ & & & & & & & $\mathrm{X}$ & & \\
\hline 87 & $\begin{array}{ll}\text { Federated } & \text { Dept. } \\
\text { Stores (FD) } & \end{array}$ & $23,347.0$ & $1,406.0$ & & & & & & $\mathrm{x}$ & & & & & & $\mathrm{X}$ & & \\
\hline 88 & $\begin{array}{l}\text { Amerada Hess } \\
(\mathrm{AHC})\end{array}$ & $23,255.0$ & $1,242.0$ & & & & & & $\mathrm{x}$ & & & & & & $\mathrm{X}$ & & \\
\hline 89 & Coca-Cola (KO) & $23,104.0$ & $4,872.0$ & & & & & & $\mathrm{X}$ & & & $\mathrm{X}$ & $\mathrm{X}$ & & & & \\
\hline 90 & $\begin{array}{l}\text { Weyerhaeuser } \\
\text { (WY) }\end{array}$ & $23,000.0$ & 733.00 .00 & & $\mathrm{X}$ & & & & & & & & & $\mathrm{X}$ & $\mathrm{x}$ & & \\
\hline 91 & Aetna (AET) & $22,885.0$ & $1,634.5$ & & & & & & $\mathrm{X}$ & & $\mathrm{X}$ & & & & & & \\
\hline 92 & $\begin{array}{l}\text { Mass. Mutual Life } \\
\text { Ins. }\end{array}$ & $22,798.8$ & $1,446.0$ & & & & & & $\mathrm{X}$ & & $\mathrm{X}$ & & & & & & \\
\hline 93 & $\begin{array}{l}\text { Abbott Laboratories } \\
\text { (ABT) }\end{array}$ & $22,337.8$ & $3,372.1$ & & $\mathrm{x}$ & & & & & & & $\mathrm{X}$ & & & & & \\
\hline 94 & Comcast (CMCSK) & $22,255.0$ & 928.00 .00 & & & & $\mathrm{X}$ & & $\mathrm{X}$ & & & & & & $\mathrm{X}$ & $\mathrm{X}$ & $\mathrm{X}$ \\
\hline 95 & Merck (MRK) & $22,011.9$ & $4,631.3$ & & & & & & $\mathrm{X}$ & & $\mathrm{X}$ & & & & $\mathrm{X}$ & & \\
\hline 96 & Deere (DE) & $21,930.5$ & $1,446.8$ & & & & & & $\mathrm{X}$ & & & & $\mathrm{X}$ & & & & $\mathrm{x}$ \\
\hline 97 & Raytheon (RTN) & $21,894.0$ & 871.00 .00 & & & & & & $\mathrm{X}$ & & & & & & $\mathrm{X}$ & & $\mathrm{x}$ \\
\hline 98 & Nationwide & $21,832.0$ & $1,149.0$ & & & & & & $\mathrm{X}$ & & & & & & $\mathrm{X}$ & & \\
\hline 99 & $\begin{array}{l}\text { Washington Mutual } \\
\text { (WM) }\end{array}$ & $21,326.0$ & $3,432.0$ & & & & & & $x$ & & & & & & $\mathrm{X}$ & & \\
\hline 100 & $\begin{array}{l}\text { General Dynamics } \\
\text { (GD) }\end{array}$ & $21,290.0$ & $1,461.0$ & & & & & $\mathrm{x}$ & & & & & & & $\mathrm{X}$ & & \\
\hline & Total & & & 7 & 9 & 6 & 12 & 9 & 65 & 9 & 15 & 14 & 3 & 9 & 58 & 18 & 27 \\
\hline
\end{tabular}

